Proc. Indian Acad. Soi., Vol. 88 B, Part II, Number 2, March 1979, pp. 143-154, $\rightarrow$ printed in India.

\title{
Isolation of intact mesophyll cells from the leaves of bigher plants
}

\author{
G RAJENDRUDU*, I MADHUSUDANA RAO*, \\ A S RAGHAVENDRA ${ }^{\dagger}$ and V S RAMA DAS* \\ Department of Botany, Sri Venkateswara University, Tirupati 517502 \\ * Present address: School of Life Sciences, University of Hyderabad, \\ Hyderabad 500001 \\ † Present address: Centro de Estudies Fotosinteticos y Bioquimicos (CEFOBI), \\ Suipacha 531, 2000 Rosario, Argentina. \\ MS received 19 May 1978; revised 2 December 1978
}

\begin{abstract}
A total of 146 species of angiosperms belonging to 35 taxonomically diverse families were screened for the isolation of living mesophyll cells from the leaves. Seventy-three species belonging to 22 families, on mild maceration in mortar with the isolation medium (pH 5.8) containing 0.7 M mannitol, $2 \mathrm{mM}$ EDTA, $5 \mathrm{mM} \mathrm{MgCl}_{2}, 5 \mathrm{mM} \mathrm{K}_{2} \mathrm{HPO}_{4}$ and $1 \mathrm{mM} \mathrm{NaNO}$, followed by fractional centrifugation, yielded intact mesophyll cells as seen under a research microscope. The high frequency of cell release, associated with the high percentage recovery of chlorophyll in cells was a common feature of most of the plant species examined by us. Nearly $87 \%$ of the chlorophyll present in the leaf could be recovered from the isolated cells in Dolichos lablab. The isolated cells retained active photosynthetic carbon metabolism as evidenced by high rates of ferricyanide reduction as well as carbon assimilation.
\end{abstract}

Keywords. Isolated cells; photosynthesis; maceration.

\section{Introduction}

Isolated intact plant cells form an ideal system for understanding metabolism. Suspensions of isolated leaf cells are particularly promising for photosynthetic studies. According to Jensen et al (1971) they are useful for both short term experiments and for metabolic studies even up to about $36 \mathrm{hr}$ after preparation.

Photosynthetically active cells have been isolated from leaves of higher plants by mild maceration in a few instances (Racusen and Arnoff 1953; Zaitlin 1959; Gnanam and Kulandaivelu 1969; Jullien and Rossini 1977). The technique of isolating leaf cells with the help of fungal enzymes in a hypertonic medium has been recently gaining popularity (Takebe et al 1968; Power and Cocking 1970; Jensen et al 1971; Evans et al 1972; Cataldo and Berlyn 1974; Schieder 1975; Bajaj 1977; Gamborg 1977). Yet the technique of cell isolaticn by mere maceration easily yields good cellular suspension, without implying the use of pectinases. 
We have screened a large number of plants of the Tirupati region (as many as 32 mono- and 114 dicotyledons including 33 crop plants) for the isolation of intact mesophyll cells by using the simple technique of mild maceration followed by fractional centrifugation.

\section{Materials and methods}

The plants used were grown under natural field conditions in the campus of Sri Venkateswara University (approximate $12 \mathrm{hr}$ photoperiod with temperatures of $35^{\circ} \mathrm{C}$ day and $25^{\circ} \mathrm{C}$ night). Some of the plants were ornamentals raised in the Botanical Garden. Fully expanded leaves were picked from the plants. The leaves were thoroughly washed with tap water followed by distilled water. The laminar tissue was cut into $\mathrm{Ca} 0 \cdot 25-0.50 \mathrm{~cm}^{2}$ pieces and suspended for $10 \mathrm{~min}$ in the isolation medium (pH 5.8) containing $0.7 \mathrm{M}$ mannitol, $2 \mathrm{mM}$ EDTA, $5 \mathrm{mM} \mathrm{MgCl}_{2}, 5 \mathrm{mM} \mathrm{K}_{4} \mathrm{HPO}_{4}$ and $1 \mathrm{mM} \mathrm{NaNO}$. The leaf pieces wcre ground very gently in $10 \mathrm{ml}$ of the isolation medium using a mortar and pestle. The degree of cell breakage and cell separation during mild maceration were observed periodically with a research microscope. The homogenate was poured into a centrifuge tube and allowed to settle for about $10 \mathrm{~min}$. The supernatant (which usually contained broken cells) was decanted and replaced by fresh isolation medium. This procedure was repeated thrice. The cell suspension was then filtered through two layers of cheese cloth and the cell-clumps retained on the cheese cloth were thoroughly washed and collected in the same medium. The cells were subsequently collected by centrifugation at $250 \mathrm{~g}$ for $2 \mathrm{~min}$. The pellet was again suspended in the fresh isolation medium. Centrifugation and resuspension were continued (usually 2 or 3 times) until the supernatant fluid was free from green colour. The cells free from debris were examined under a research microscope.

The cell number in the suspensions $(50 \mu \mathrm{l})$ was determined using Neubauer improved double Haemocytometer. The total chlorophyll content of the cell suspensions as well as whole leaves was determined according to the method of Arnon (1949).

The carbon assimilation capacity of isolated mesophyll cells was determined in terms of incorporation of radioactivity from $\mathrm{NaH}^{\mu} \mathrm{CO}_{3}$ into acid stable products. The reaction mixture $(2 \mathrm{ml})$ contained $0.4 \mathrm{M}$ mannitol, $2 \mathrm{mM}$ EDTA, $5 \mathrm{mM} \mathrm{MgCl}, 1 \mathrm{mM} \mathrm{NaNO}, 1 \mathrm{mM} \mathrm{MnCl}, 5 \mathrm{mM} \mathrm{K}_{2} \mathrm{HPO}_{4}, 50 \mathrm{mM}$ tricine buffer $\mathrm{pH} 8 \cdot 0,5 \mathrm{mM} \mathrm{NaH}{ }^{14} \mathrm{CO}_{3}$ and cell suspension (equivolant to $15-20 \mu \mathrm{g}$ chlorophyll/ $\mathrm{ml}$ ). The illumination was provided by incandescent bulbs and the light intensity after passing through a $10 \mathrm{~cm}$ water filter was $200 \mathrm{w} \mathrm{m}^{-2}$. The reaction was terminated by the addition of $0.5 \mathrm{ml}$ of $5 \mathrm{~N} \mathrm{HCl}$. The ${ }^{14} \mathrm{C}$ incorporation was determined using a GM counter.

Ferricyanide reduction was followed as the decrease in absorbance at $420 \mathrm{~nm}$ (Raghavendra and Das 1978b).

\section{Results}

Out of the 146 species screened, 73 species belonging to 22 families yielded intac mesophyll cells on mild maceration (table 1). The washed cells (a few appear as 


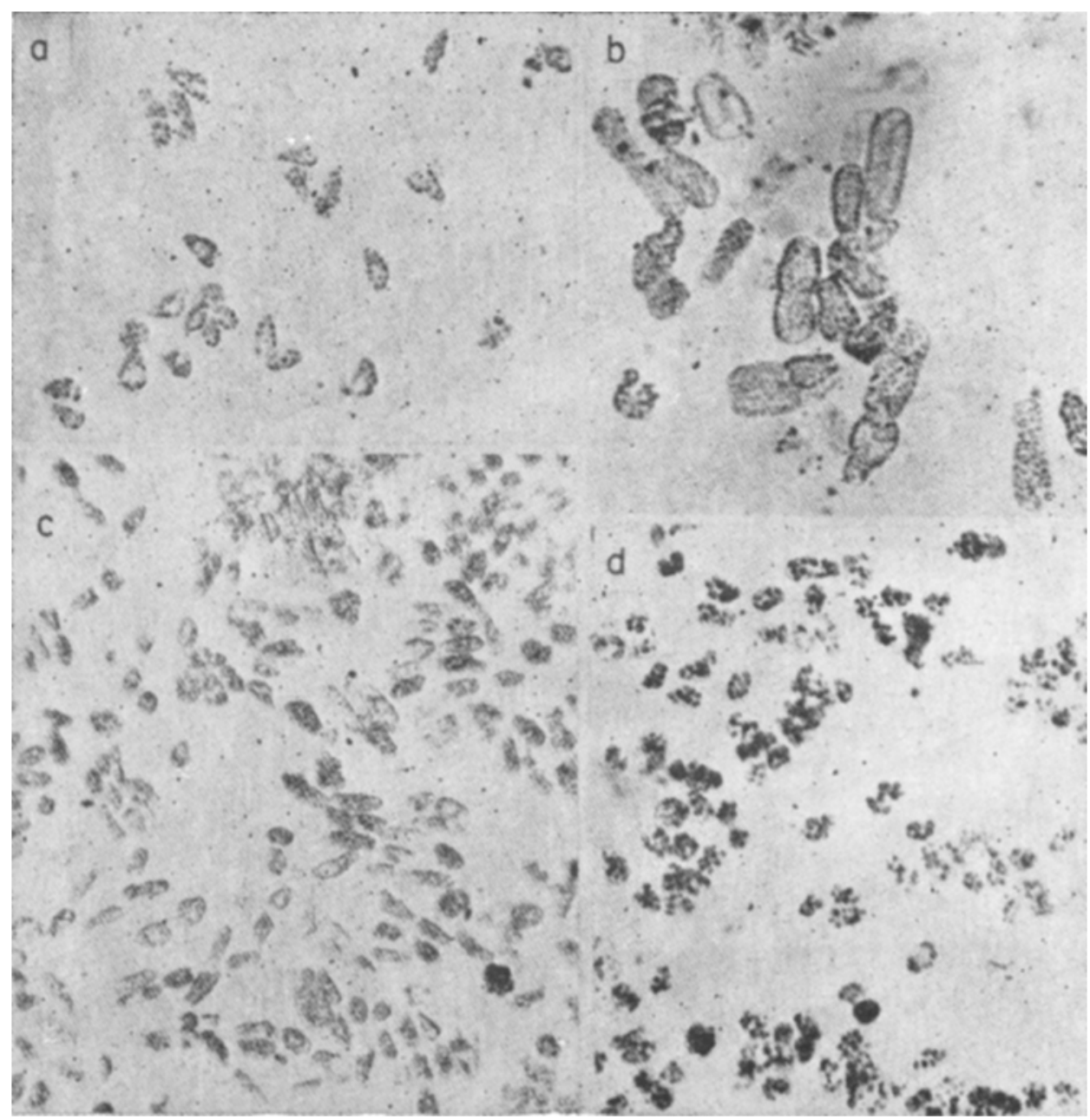

Figure 1. Intact mesophyll cells isolated from leaves of Commelina benghalensis (a), Celosia cristata (b), Arachis hypogaea (c) and Digitaria adscendens (d) $\times 150$. 


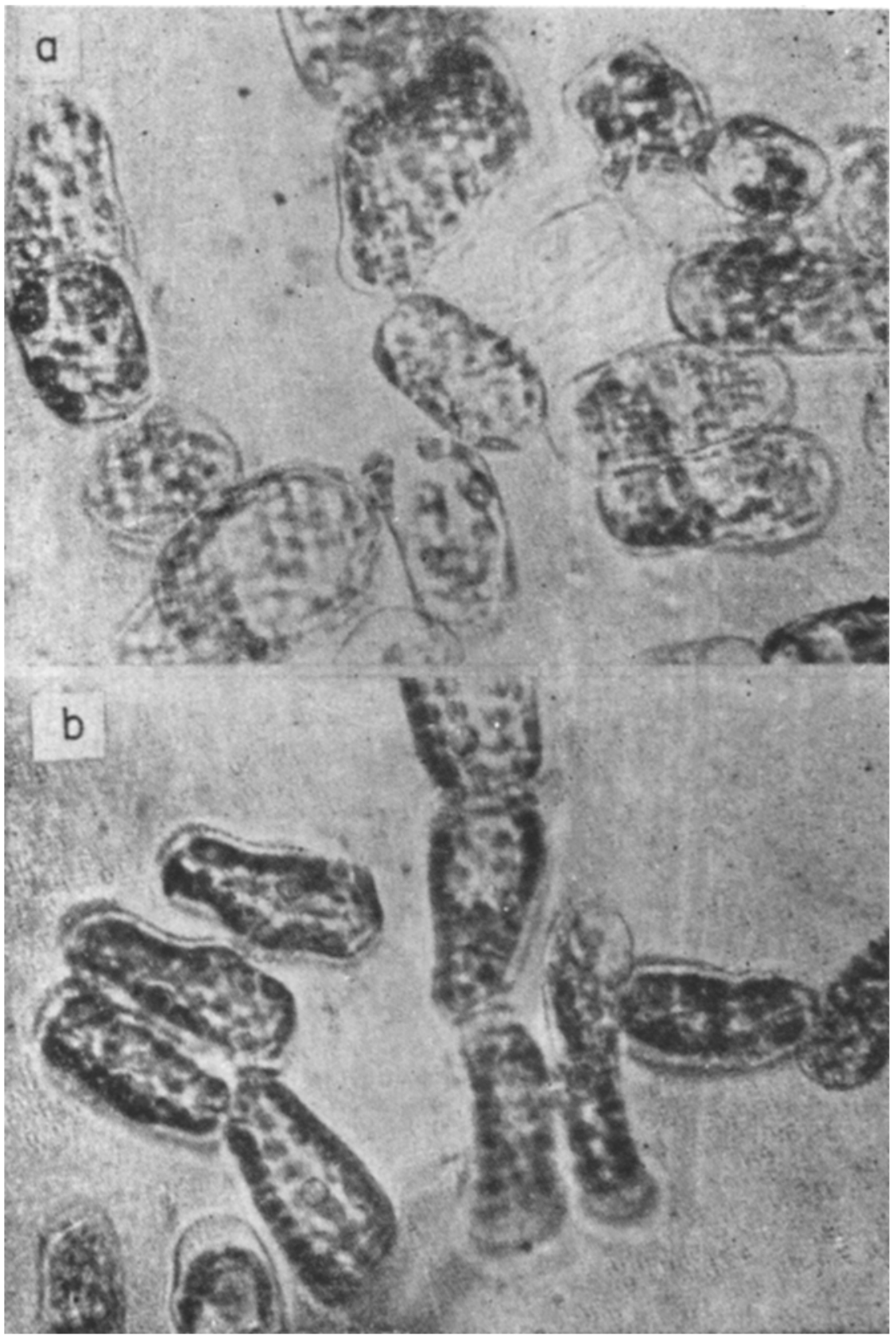

Figure 2. Intact mesophyll celıs isolated from leaves of Digera alternifolia (a) and Aster leavis (b) 600 . 
Table 1. List of plant species screened for yield of intact mesophyll cell suspensions.

1. Acanthaceae

\section{Dicots}

Andrographis echioides (L.) Nees

Barleria buxifolia L.

Blepharis mollugtnifolia Pers.

Crossandra infundibuliformis (L.) Nees

Justicia prostrata Gamb.

J. tranquebariensis L.f.

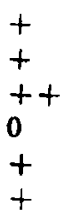

2. Aizoaceae

Mollugo microphylla $\mathbf{R}$.

$M$. nudicaulis Lamk.

$M$. pentaphylla $\mathrm{L}$.

3. Amaranthaceae

Achyranthes aspera $\mathrm{L}$.

Allmania nodiflora R.Br.

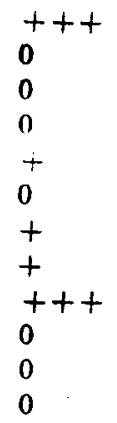

4. Apocynaceae

Carissa spinarum $\mathrm{L}$.

Rauvolfia serpentina Benth.

Catharanthus rosens (L.) G.Don.

Amaranthus tricolor $\mathbf{L}$.

A. spinosus $\mathrm{L}$.

A. viridis $\mathrm{L}$.

Celosia argentea $\mathbf{L}$.

C. cristata $\mathrm{L}$.

Cra alternifolia (L.) Aschers.

G. globosa L.

Alternanthera ficoides (L.) R.Br. ex R.

5. Asclepiadaceae

Calotropis gigantea R.Br.

Leptadenia reticulata W \& A.

0

0

6. Asteraceae (Compositae)

Acanthospermum hispidum DC.

Aster leavis L.

Carthamus tinctorius $\mathbf{L}$.

Eclipta prostrata (L.) L.

Guizotia abyssinica Cass.

Glossocardia bosvallea DC.

Gaillardia sp.

Helionthus annuus $\mathrm{L}$.

Tagetes patulas $\mathrm{L}$.

Tridax procumbens $\mathrm{L}$.

Vernonia cinerea ( $L$.) Less.

Zinnia elegans Jacq.

0

0

0

$+t$ 
Table 1. (Conid.)

7. Capparidaceac

Cleome viscosa $\mathrm{L}$.

Cleome gynandra (L.) Briv.

$$
++
$$

0

0

Casuarina equisetifolia Forst.

9. Caryophyllaceac

Polycarpaea corymbosa (L.) Lamk.

0

10. Chenopodiaceae

Chenopodium amaranticolar Coste and Reyn Chenopodium quinova

11. Convolvulaceat

Evolvulus alsinvides $\mathrm{L}$.

Ipomoea tridentata Roth.

I. tuberosa $\mathrm{L}$.

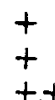

12. Cruciferae (Brassicaceae)

Brassica juncea (L.) Czern. and Cosi.

Raphanus sativus $\mathrm{L}$.

0

13. Euphorbiaceac

Acalypha indica $\mathbf{L}$.

Euphorbia hirta $\mathbf{L}$.

E. pulcherrima Willd.

E. milii Ch.-des-Moullins

Phyllanthus maderaspatensis $\mathbf{L}$.

P. fraternus Webster

Ricinus communis L.

Sebastianiu chaemaelea M.-Arg.

0

0

$+$

0

$+$

$+t$

0

$+$

14. Balsaminaceae

Impatiens balsamina $\mathbf{L}$.

15. Labiatae (Lamiaceae)

Anisomeles malabarica R.Br.

Coleus aromaticus Benth.

Leucas aspera Spr.

L. linifolia Spr.

Ocimum basilicum $\mathrm{L}$.

O. sancrum $\mathrm{L}$.

+
+
0
0
0
0
0

16. Leguminosae (Fabaceae)

Acacia leucophloea (Roxb.) Willd.

A. sundra DC.

A. latronum Willd.

Alysicarpus monilifer DC.

Arachis hypogaea Willd.

Cajanus cajan (L.) Millsp.

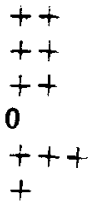


Table 1 (Contd.)

Cassia auriculata $\mathrm{L}$.

C. raxburghii DC.

Crotalaria retusa $\mathrm{L}$.

Cyamopsis tetragonoloba (L.) Taub.

Dolichos lablab L.

Heylandia latebròsa DC.

Indigofera linnaei Ali.

Prosopis juliflora (SW.) DC.

Rhynchosia minima (L.) DC.

Teramnus labialis (L.f.) Spr.

Vigna sinensis (L.) Saviex Hassak.

Zornia diphylla (L.) Pers.

o

0

0

$+$

$++t$

$+$

$+t$

$++$

$++$

$+$

0

$++$

17. Malvaceae

Gossypium hirsutum $\mathbf{L}$.

Hibiscus micranthus L.f.

Pavonia zeylanica Cav.

Sida acuta Burm.f.

S. glutinosa Cav.

18. Myrtaceae

Eucalyptus globulus Labill.

Psidium guajava $\mathbf{L}$.

0

0

19. Nyctaginaceae

Boerhavia diffusa $\mathbf{L}$.

B. repanda Willd.

Bougrainvillea spectabilis Willd.

0

o

o

20. Pedalisceae

Sesamum orientale $\mathbf{L}$.

0

21. Piperaceae

Peperomia hybrida $\mathrm{L}$.

0

22. Portulacaceae

Portulaca oleracea $\mathbf{L}$.

0

23. Rhamnaceae

Ziryphus mauritiana Lamk.

$++$

24. Rubiaceae

Borreria articularis (L.f.) F.N. Williams

Chomelia asiatica $\mathbf{O}$. Kze.

Oldenlandia umbellata $\mathrm{L}$.

Randia dumetorum Lamk.

R. malabarica Lamk.

$+$

0

$+$

$+$

$++$

25. Sapindaceae

Dodonaea viscosa Jacq.

0

$+$

$+$

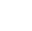

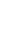


Tabie 1 (Consd.)

Plant species

Cell releaso*

26. Solanaceac

Capsicum frutescens $\mathbf{L}$.

Datura fastuosa $\mathrm{L}$.

Lycopersicum esculentum Mill.

Nicotiana tabacum $\mathbf{L}$.

Physalis minima L.

Solanum melongena $L$.

$S$. nigrum $\mathrm{L}$.

0

0

0

0

0

0

0

27. Umbelliferae (Apiaceac)

Coriandrum sativum $\mathbf{L}$.

0

28. Urticaceae

Pilea microphylla (L.) Liebm.

0

29. Verbenaceare

Clerodendrum inerme Gaertn.

Lantana camara $\mathbf{L}$.

0

$++$

0

Tribulus terrestris $\mathbf{L}$.

Monocots

31. Commelinaceae

Commelina benghalensis $\mathrm{L}$.

C. clavata $\mathbf{C l}$.

$++$

$+t$

32. Cyperaceae

Bulbostylis barbata Kunth

Cyperus compressus $\mathbf{L}$.

C. rotundus $\mathrm{L}$.

$+$

$+t$

$++$

33. Musaceae

Musa paradisiaca $\mathrm{L}$.

$++$

34. Typhaceae

Typha latifolia $\mathrm{L}$.

$+t$

35. Gramineac (Poaceae)

Alloteropsis cimicina Stapf

o

Aristida hystrix $\mathbf{L}$.

Bambusa arundinacea (Retz.) Willd.

Brachiaria mutica Stapf

Cenchrus ciliaris $\mathbf{L}$.

Chloris barbata Sw.

C. gayana Kunth

Coix aquatica

Cynodon dactylon Pers.

Dactyloctenium aegyptium Beauv.

Digitaria adscendens Henr.
0

0

$+$

$+$

$+$

$+$

0

$+$

$+$

$++$ 
Twila 1 (Contd.)

\begin{tabular}{lc}
\multicolumn{1}{c}{ Plant species } & Cell release \\
\hline Echinochloa colonum Link & + \\
Eleusine coracana Gaertn. & 0 \\
Heteropogon contortus Beauv. & + \\
Imperata cylindrica Beauv. & 0 \\
Oryza sativa L. & 0 \\
Panicum maximum Jacq. & + \\
P. nodosum Kunth & + \\
P. psilopodium Trin. & + \\
P. purpurascens Raoldi & + \\
Saccharum officinarum L. & + \\
Sorghum vulgare L. & 0 \\
Spinifex squarrosus L. & 0 \\
Tragus bifiorus Schult. & + \\
Zea mays L. & 0
\end{tabular}

- Degree of cell release: + poor; ++ average; +++ good; 0 without cells.

clumps) were morphologically intact as demonstrated by photomicrographs (figures 1 and 2).

The high frequency of cell release, associated with the high percentage recovery of chlorophyll in cells was a common feature of most plants excepting Digitaria adscendens, Digera alternifolia and Randia malabarica. These three species show low cell number per gram fresh weight with high percentage recovery of chlorophyll in cells (table 2). Dolichos lablab was most ideally suited for cell isolation as indicated by the maximum recovery of chlorophyll in the cells.

The isolated mesophyll cells were photosynthetically active as indicated by active carbon fixation as well as ferricyanide reduction. The carbon fixation rates of four species ranged from 62-124 $\mu$ moles $\mathrm{mg} \mathrm{chl}^{-1} \mathrm{hr}^{-1}$ (table 3). The rate of ferricyanide reduction by the cells of Dolichos exhibited linearity even up to $10 \mathrm{~min}$ unlike those of Digitaria in which linearity was evident only for $3 \mathrm{~min}$ (figure 3 ). The cells of Dolichos exhibited a lag phase before attaining maximal rates of "Cassimilation. The cells of Digitaria did not show any lag phase during carbon fixation.

\section{Discussion}

Racusen and Arnoff (1953) found for the first time that soybean leaf cells could be separated by mild grinding in a mortar. Gnanam and Kulandaivelu (1969) were able to separate intact cells from several plants belonging to 17 families including monocotyledons by mild grinding in a mortar. In the present study, a large number of plant species have yielded intact mesophyll cells and thus have added to the list of plant species studied earlier (Gnanam and Kulandaivelu 1969; Bajaj 1977; Jullien and Rossini 1977). Although in majority of the plant species, the high frequency of cell release was always associated with a high percentage recovery 


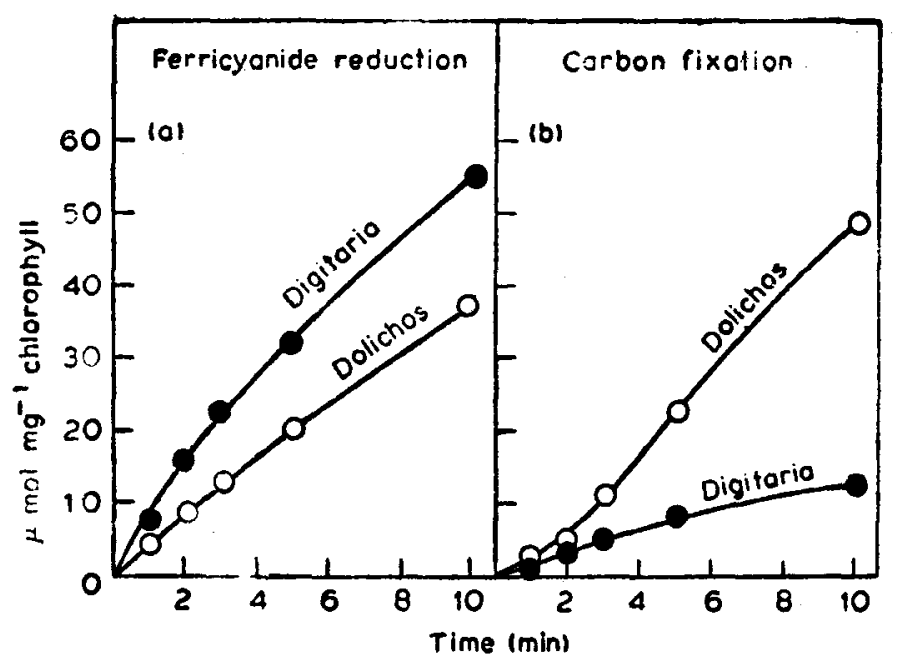

Fhgure 3. The pattern of ferricyanide reduction (a) and carbon assimilation (b) by isolated mesophyll cells from Digitaria adscendens and Dolichos lablab.

Table 2. Cell release and chlorophyll recovery of isolated mesophyll cells from different plant species (values are means of five observations $\pm \mathrm{SE}$ ).

\begin{tabular}{|c|c|c|c|c|}
\hline \multirow[t]{2}{*}{ Plant species } & \multirow{2}{*}{$\begin{array}{l}\text { Number of } \\
\text { cells released } \\
\text { per } g \text { fresh } \\
\text { weight }\left(\times 10^{7}\right)\end{array}$} & \multicolumn{2}{|c|}{$\begin{array}{l}\text { Total chlorophyll } \\
\text { (mg } \mathrm{g}^{-1} \text { fresh weight) }\end{array}$} & \multirow{2}{*}{$\begin{array}{l}\text { Per cent } \\
\text { recovery of } \\
\text { chlorophyll } \\
\text { in cells }\end{array}$} \\
\hline & & Leaves & Cells & \\
\hline Arachis hypogaea & $5 \cdot 60$ & $2 \cdot 08 \pm 0 \cdot 18$ & $1 \cdot 59 \pm 0 \cdot 11$ & $76 \cdot 4 \pm 6 \cdot 2$ \\
\hline Dolichos lablab & $6 \cdot 60$ & $2 \cdot 31 \pm 0 \cdot 17$ & $2 \cdot 02 \pm 0 \cdot 16$ & $87 \cdot 4 \pm 8 \cdot 8$ \\
\hline Musa paradisiaca & $2 \cdot 30$ & $1 \cdot 63 \pm 0 \cdot 12$ & $0.73 \pm 0.05$ & $44 \cdot 8 \pm 3 \cdot 9$ \\
\hline Justicia tranquebarlensis & $0 \cdot 50$ & $3 \cdot 36 \pm 0 \cdot 26$ & $0.44 \pm 0.02$ & $13 \cdot 2 \pm 1 \cdot 2$ \\
\hline Randia malabarica & $1 \cdot 25$ & $1 \cdot 90 \pm 0 \cdot 12$ & $1 \cdot 09 \pm 0 \cdot 11$ & $57 \cdot 4 \pm 4 \cdot 9$ \\
\hline Commelina benghalensis & $2 \cdot 15$ & $2 \cdot 54 \pm 0 \cdot 21$ & $1 \cdot 21 \pm 0 \cdot 09$ & $47 \cdot 6 \pm 3 \cdot 6$ \\
\hline Chenopodium quinova & $1 \cdot 75$ & $1 \cdot 51 \pm 0 \cdot 10$ & $0.44 \pm 0.03$ & $29 \cdot 1 \pm 2 \cdot 6$ \\
\hline Cleome viscosa & $5 \cdot 16$ & $2 \cdot 22 \pm 0 \cdot 19$ & $1 \cdot 37 \pm 0 \cdot 12$ & $61 \cdot 7 \pm 5 \cdot 7$ \\
\hline Digera alternifolia & 2.94 & $1 \cdot 98 \pm 0 \cdot 11$ & $0.89 \pm 0.06$ & $44 \cdot 9 \pm 4 \cdot 8$ \\
\hline Digltaria adscendens & 2.04 & $2 \cdot 05 \pm 0.23$ & $1 \cdot 36 \pm 0 \cdot 11$ & $66 \cdot 5 \pm 5 \cdot 9$ \\
\hline Achyranthes aspera & 4.92 & $2 \cdot 78 \pm 0 \cdot 20$ & $1 \cdot 36 \pm 0 \cdot 14$ & $48 \cdot 9 \pm 4 \cdot 6$ \\
\hline Panicum maximum & 0.90 & $1.42 \pm 0.09$ & $0.62 \pm 0.05$ & $43 \cdot 6 \pm 3 \cdot 8$ \\
\hline Cyperus rotundus & $4 \cdot 20$ & $1 \cdot 71 \pm 0 \cdot 12$ & $1.03 \pm 0.09$ & $60 \cdot 2 \pm 7 \cdot 2$ \\
\hline Celosia argentea & 0.42 & $1 \cdot 62 \pm 0 \cdot 15$ & $0.54 \pm 0.03$ & $33 \cdot 3 \pm 2 \cdot 8$ \\
\hline
\end{tabular}

of chlorophyll in cells. There were exceptions like Digitaria adscendens, Digera alternifolia and $R$. malabarica (table 2).

The fact that isolated mesophyll cells are a useful system to study the photosynthetic reactions was demonstrated by the high rates of ferricyanide reduction 
Table 3. Photosynthetic carbon fixation and ferricyanide reduction rates by isolated cells.

\begin{tabular}{lcc}
\hline Plant species & $\begin{array}{c}\text { Ferricyanide reduc- } \\
\text { tion } \mu \text { moles } \mathrm{mg}^{-1} \\
\text { (chlorophyll) h }\end{array}$ & $\begin{array}{c}{ }^{14} \mathrm{CO}_{2} \text { assimilation } \\
\mu \text { moles } \mathrm{mg}^{-1} \\
\text { (chlorophyll) } \mathrm{h}^{-1}\end{array}$ \\
\hline Arachis hypogaea & $230 \cdot 6$ & $110 \cdot 4$ \\
Digera alternifolia & $330 \cdot 8$ & $96 \cdot 8$ \\
Digitaria adscendens & $450 \cdot 2$ & $62 \cdot 4$ \\
Dolichos lablab & $280 \cdot 0$ & $124 \cdot 2$ \\
\hline
\end{tabular}

and carbon fixation capacity of intact cells (table 3). The carbon fixation rates recorded in the present investigation appear to be high as compared to those obtained in the earlier attempts, i.e., without the addition of any substrate (Edwards et al 1970; Edwards and Black 1971; Jensen et al 1971; Rehlfeld and Jensen 1973).

The data on time course of ferricyanide reduction and carbon fixation by intact mesophyll cells are particularly interesting and resemble the pattern in isolated chloroplasts. The cells of Dolichos $\left(\mathrm{a}_{3}\right.$ plant) exhibited an initial lag phase during carbon fixaticn and the rates of ferricyanide reduction were linear for longer period. On the other hand the absence of lag phase during carbon fixation by cells of Digitaria (a $\mathrm{C}_{4}$ plant) was associated with maintenance of linearity in ferricyanide reduction for only shorter durations. The chloroplasts from the leaves of $\mathrm{C}_{4}$ plants, Amaranthus paniculatus, Pennisetum typhoides and Setaria italica do not have a lag phase during carbon fixation (Raghavendra and Das 1978b) and also maintain linear rates of not only carbon fixation but also photochemical activities for shorter duration as compared to those from $\mathrm{C}_{3}$ plants, Oryza sativa and Rumex resicarius (Raghavendra and Das 1978a).

\section{Acknowledgements}

This investigation was supported by a grant from the Science and Engineering Research Council, Department of Science and Technology, Government of India, New Delhi.

\section{References}

Amon D I 1949 Copper enzymes in isolated chloroplasts. Polyphenol oxidase in Beta vulgaris; Plant Physiol. 24 1-15

Bajaj Y P S 1977 Protoplast isolation, culture and somatic hybridisation; in Applied and fundamental aspects of plant cell, tissue, and organ culture, eds. J Reinert and Y P S Bajaj (Berlin Heidelberg, New York, Springer-Verlag) ch. IV. pp. 5, 467.496

Cataldo D A and Berlyn G P 1974 An evolution of selected physical characteristics and metabolism of enzymatically separated mesophyll cells and minor veins of tobacco; Am. J. Bot.61 957-963 
Edwards G E and Black C C 1971 Isolation of mesophyll cells and bundle sheath cells from Digitaria sanguinalis (L.) Scop. leaves and a scanning microscopy study of the internal leaf cell morphology; Plant Physiol. 47 149-156

Edwards G E, Lee S S, Chen T M and Black C C 1970 Carboxylation reactions and photosynthesis of carbon compounds in isolated mesophyll and bundle sheath cells of Digitaria sanguinalis (L.) Scop.; Biochem. Biophys. Res. Commun. 39 389-395

Evans P K, Keates A G and Cocking E C 1972 Isolation of protoplasts from cereal leaves,; Planta 104 178-181

Gamborg O L 1977 Somatic cell hybridization by protoplast fusion and morphogenesis; in Plant tissue culture and its bio-technological application eds W Barz, E Reinhard and M H Zonk (Berlin-Heidelberg, New York: Springer-Verlag) pp. 287-301

Gnanam A and Kulandaivelu G 1969 Photosynthetic studies with leaf cell suspensions from higher plants; Plant Physiol. 44 1451-1456

Jensen R G, Francki R I B and Zaitlin M 1971 Metabolism of separated leaf cells. I. Preparation of photosynthetically active cells from tobacco; Plant Physiol. 48 9-13

Jullien M and Rossini L 1977 L'Lóbention de cellules séparées a partir du tissu foliaire chez less plantes suspérieures: intérét et potentialités d'une methode mécanique; Ann. Amelior. Plant. 27 87-103

Power J B and Cocking E C 1970 Isolation of leaf protoplasts: Imacro-molecule uptake and growth substance response; J. Exp. Bot. $2164-70$

Racusen D W and Arnofr S 1953 A homogeneous cell preparation from soybean leaves; Science 118 302-304

Raghavendra A S and Das V S R 1978a Photochemical activities of chloroplasts isolated from plants with the $\mathrm{C}_{4}$-pathway of photosynthesis and from plants with the Calvin cycle; $Z$. Pflanzenphysiol. 68 1-11

Raghavendra A S and Das V S R 1978b Carbon fixation pattern in chloroplasts isolated from $\mathrm{C}_{3^{-}}$and $\mathrm{C}_{4}$-plants; Photosynthetica 12 166-177

Rehfeld D W and Jensen R G 1973 Metabolism of separated leaf cells. III. Effects of calcium and ammonium on product distribution during photosynthesis with cotton leaves; Plant Physiol. $52 \quad 17-22$

Schieder D 1975 Selection of somatic hybrid between autotrophic mutants of Sphaerocarpos donnellii Aust. using the method of protoplast fusions; Z. Pflanzenphysiol. 74 357-365

Takebe I, Otsuki Y and Aoki S 1968 Isolation of tobacco mesophyll cells in intact and active state; Plant Cell Physiol. 9 115-124

Zaitlin M 1959 Isolation of tobacco leaf cells capable of supporting virus multiplications; Nature (London) 184 1002-1003 